\title{
Challenges of Service Deliveries in Public Institutions: Evidence from Adama and Addis Ababa City Administrations of Ethiopia
}

\author{
Mesfin Seyoum \\ School of Policy Studies, Ethiopian Civil Service University, PO Box 5648, Addis Ababa, Ethiopia
}

\begin{abstract}
Over the past decade, discussions on concept of good governance in public service deliveries have been unsystematic. Improved public service deliveries through the effective use of citizen engagement policies and strategies by governments and other governance actors are not explored. This study undertook empiricallygrounded research focusing on "how" public services are provided, rather than on "which" services are provided. The research attempted to use both qualitative and quantitative data, employing probability and non-probability sampling techniques to collect data at different stages. The previous evidence revealed that while ineffective service delivery are considerable challenges faced by public service, they are not insurmountable. Especially, the principles that can objectively guide the public service institutions, not only on service delivery standards, but also on public participation as well is not strictly followed by the institution under study. Citizens are not just consumers of services rendered by government, but are also critical role players with a stake in the election of governments and how such governments should run the affairs of the country.
\end{abstract}

Keywords: Good governance, Decentralization, Participation, Service delivery

DOI: $10.7176 /$ PPAR/10-7-01

Publication date:July $31^{\text {st }} 2020$

\section{Introduction}

The involvement of citizens in matters of service deliveries is important for good governance as it promotes social cohesion between government and the citizens, particularly in the provision of public services (Blair 2000, Goetz $\&$ Gaventa 2001). Citizens are not just consumers of services rendered by government, but are also critical role players with a stake in the election of governments and how such governments should run the affairs of the country. People, as both citizens and consumers of services, should be allowed and encouraged to express their views on governance and service deliveries matters (Bartley 1999). Public services providers should adopt to the necessary principles in order to respond to community and citizens need and preferences.

\subsection{Statements of Problem}

Over the past decade, discussions on public service deliveries have been unsystematic (Claasen 2011). So far, improved public service deliveries through the effective use of citizen engagement policies and strategies by governments and other governance actors are not explored (Dukhira, 2000, learnt Goertz \& Jenkins 2001). Given the recent incident of public discontent resulting in violent popular uprising, protest and huge distraction in terms of both material and human loss in Ethiopia, this study undertook empirically-grounded research on the practice of government institutions in public service deliveries. It emphases on "how" public services are provided, rather than on "which" services are provided and its main intent is to improve the efficiency and effectiveness of the ways in which the public services are delivered.

\subsection{General objectives of the study}

To assess challenges of service deliveries in public institutions focusing on selected public sector in Adama and Addis Ababa city administrations

Specific objectives

- To compare practices of service deliveries in the study cities

- To investigate factors for public dissatisfaction in matters related to service deliveries in both study sites

- To explore challenges inhabiting the efficiency and effectiveness of service deliveries in public institutions.

\section{Factors for effective public service deliveries}

Service deliveries is not a simple, single-track activity. It is a combination of several factors as discussed in the following sections.

\section{- Service standards}

The standards are the tools we can use to measure our performance, and therefore need to be realistic depending on available resources. We should also be able to measure these standards so that everyone can see if they are 
being met. It is about informing citizens about the level and quality of services rendered by government. By so doing, citizens know what to expect from government, by when that service will be delivered, and channels to be taken where there are complaints in relation to the service(Baines 1996)

- Accessing the public service

It means taking our services out to the community. One of the prime aims of good governance in a democratic government is to provide a framework for making decisions about delivering public services to the many citizens who were and still are denied access to them (Ngouo 1997). In setting these targets, institutions which promote the interests of previously disadvantaged groups, such ast youth and women association and groups representing the disabled should be consulted (Glaser, Yeager \& Parker 2006).

- Courtesy

Courtesy manifested when citizens are treated with respect and consideration when they interact with government officials for purpose of accessing services. The Code of Conduct for public servants distributed by the Public Service Commission of Ethiopia made it clear that courtesy and regard for the public is one of the fundamental duties of public servants, by specifying that public servants treat members of the public as customers who are entitled to receive the highest standards of service (Lowndes, Pratchett \& Stoker 2001).

- Information

Information is about reaching all customers to make sure they are well informed about the services the government institutions provide. It is about citizens being given information that is accurate about government services that they are entitled to, as this will in turn enable citizens to make informed choices about services they require (Kelly \& Swindell 2002).

- Openness and Transparency

Openness and transparency are the pillars of a democratic government. In terms of public service deliveries, their importance lies in the need to build confidence and trust between the public sector and the public they serve(Ebdon 2002). Since the resources of government belong to citizens, allowing them to ask questions and responding to their queries honestly and frankly has paramount importance (Glaser, Yeager \& Parker 2006).

- Accountability

The responsibility of government body has to be clearly defined and that responsible body has to be answerable to its decision and activity. If customers are treated unequally or evicted without enough compensation from their holding, the responsible body has to be accountable for its misbehaved decisions and the negative act (Biela 2010).

- Redress

Remedying mistakes or responding swiftly and sympathetically when standards of service fall below the promised level. An apology, full explanation and effective, speedy remedy should be offered when the promised standards of service have not been delivered (Denhardt \& Denhardt 2003).

- Value for many

One of the key aims of the government institutions should be to search for ways to simplify procedures and eliminate waste and inefficiency (Dijk \& Fransen eds. 2008). We need to make the best use of available resources by avoiding wastage of time, money, and other resources. Not giving a member of the public a simple, satisfactory explanation to an enquiry may result in an incorrectly completed application form which will cost time and money.

\section{Research Methodology}

- $\quad$ Types of Research

The descriptive and exploratory types of research was used in the study area to interpret and reduce the data into a summary form; that is, in tabulations, charts and bar graphs.

- Sampling Procedures and Sample Size

The study used both probability and non-probability sampling techniques to collect data at different stages. With regard to sample size, a simplified formula provided by Yamane (as cited in Yilma 2005) was used to determine the minimum sample size at $95 \%$ level of confidence with $5 \%$ margin of error (e):

$$
\mathrm{n}=\frac{\mathrm{N}}{1+\mathrm{N}(\mathrm{e})^{2}}
$$

Where ' $n$ ' is the minimum sample size, ' $N$ ' is the total number of the study population in all study sectors and ' $e$ ' is the level of precision. 
Table 3.1: Selected public sectors in the study cities

\begin{tabular}{|l|l|l|l|l|l|}
\hline \multirow{2}{*}{ no } & Name of public sectors & Custemers of selected institutions & Proportionally selected sample size \\
\cline { 3 - 6 } & & Addis Ababa & Adama City & Addis Ababa & Adama \\
\hline 1 & Office of Municipalities & 200 & 150 & 82 & 69 \\
\hline 2 & Trade and Industry & 250 & 180 & 102 & 83 \\
\hline 3 & Ethiopian Electric Authority & 160 & 120 & 65 & 56 \\
\hline 4 & Water Authority & 125 & 90 & 51 & 42 \\
\hline \multicolumn{2}{|l|}{ Total } & $\mathbf{7 3 5}$ & $\mathbf{5 4 0}$ & $\mathbf{3 0 0}$ & $\mathbf{2 5 0}$ \\
\hline
\end{tabular}

Source: (BoFED, 2017)

\section{Data Presentation, Analysis and Interpretation}

- Gender composition of the service users

Table 4.1: Gender Compositionof the respondents

\begin{tabular}{|l|l|l|}
\hline Study area & Male & Female \\
\hline Adama & $176(0.704)$ & $74(0.296)$ \\
\hline Addia Ababa & $187(0.62)$ & $113(0.38)$ \\
\hline Total & $363(66)$ & $187(34)$ \\
\hline
\end{tabular}

* The Number in the bracket indicates percentages out of hundred

Source: (Field Data, 2018)

Regarding gender composition of the service users in both study cities, 176(70.40\%) of respondents in Adama were male while 187(62.33\%) of them are males in Addis Ababa. From these $29.60 \%$ of them are female in Adama while $37.67 \%$ of them are female in Addis Ababa. The figure clearly revealed that most of the respondents that visit government office were male in both study cities and institutions.

Table 4.2: Educational level of respondents

\begin{tabular}{|l|l|l|l|l|l|l|}
\hline Study Area & \multirow{2}{*}{ Un educated } & \multicolumn{2}{|l|}{ Grade } & \multirow{2}{*}{} & \multicolumn{2}{l|}{ Degree } \\
\cline { 3 - 4 } & & $(1-8)$ & $(9-12)$ & Diploma & BA & MA \\
\hline Addis Ababa & $21(7)$ & $76(25)$ & $113(38)$ & $46(15)$ & $37(12)$ & $7(2)$ \\
\hline Adama & $21(8.4)$ & $71(28.4)$ & $98(39)$ & $32(12.8)$ & $32(10)$ & $3(1.2)$ \\
\hline Total & $42(15.4)$ & $147(54)$ & $211(77)$ & $78(28)$ & $69(22)$ & $10(4)$ \\
\hline
\end{tabular}

* The Number in the bracket indicates percentages out of hundred

Source: (Field Data, 2018)

As shown in the above Table 4.1,21(7\%) of the respondents are uneducated in AddisAbaba, while there were only $21(8.4 \%)$ of them are uneducated in Adama. 37(12\%) of the respondents are BA holders in Addis Ababa while $32(10 \%)$ of them are BA holders in Adama cities. There are also MA holders among the respondents in both cities. These clearly shows the respondents diversity in terms of their education level. Generally, there are no significant differences in terms of educational level of the respondents both in addis Ababa and Adama.These also implies that service providers need to recognize that their customers are with different educational background which requires special consideration for those who are in need.

- Duration of the respondents in the cities

Table 4.3: respondents duration in the cities

\begin{tabular}{|l|l|l|l|l|l|}
\hline Study Area & Below 5 years & $\mathbf{5 - 1 0}$ years & $\mathbf{1 1 - 2 0}$ years & $\mathbf{2 1 - 3 0}$ years & 31-40 years \\
\hline Adama & $12(4.8)$ & $67(26.8)$ & $119(47.6)$ & $34(13.6)$ & $18(7.2)$ \\
\hline Addis Ababa & $8(2.7)$ & $124(41.3)$ & $73(24.1)$ & $61(20.3)$ & $34(11.3)$ \\
\hline Total & $20(3.6)$ & $191(34.7)$ & $192(34.9)$ & $95(17.30)$ & $52(9.5)$ \\
\hline
\end{tabular}

Source: (Field Data, 2018)

As shown in the above table, the number of years the respondents have lived in the cities has paramaunt importance to understand the practice of service delivery in their respective city. In this regard, only $12(4.8 \%)$ of the respondents in Adama and 8(2.7) of them in Addis Ababa have lived below five years in their respective city. This shows 530(96.4\%) of the respondents have lived more than five years in their respective city which enable them to undertand and experience the practice of service delivery in the study instititutions. 
- Primary occupations of the respondents

Table 4.4: Primary occupations of the respondents in the study sites

\begin{tabular}{|l|l|l|l|l|l|l|}
\hline Study Area & $\begin{array}{l}\text { Government } \\
\text { employee }\end{array}$ & $\begin{array}{l}\text { Non-gov't } \\
\text { employee }\end{array}$ & $\begin{array}{l}\text { Self- } \\
\text { employed }\end{array}$ & Daily laborer & Student & Unemployed \\
\hline Addis Ababa & $124(41.1)$ & $11(3.6)$ & $79(26.3)$ & $27(9.1)$ & $8(2.7)$ & $51(17.4)$ \\
\hline Adama & $116(46.3)$ & $11(4.4)$ & $58(23)$ & $17(6.8)$ & $9(3.6)$ & $39(15.6)$ \\
\hline Total & $240(87.7)$ & $22(8.1)$ & $137(49.2)$ & $44(15.8)$ & $17(6.2)$ & $90(32.6)$ \\
\hline
\end{tabular}

* The Number in the bracket indicates Percentages out of hundred

Source: (Field Data, 2018)

The table above clearly dipictes that almost all type of occupations are service user where majority, $240(87.7 \%)$ and $137(49 \%)$ are from government employee and self employed. These indicates that service givers are expected to meet the the expectations of diffrent category of the citizens who came with diversity of priority and urgency.

- Participation of people in service deliveries

Table 4.5: Consulting the client in the deliveries of service

\begin{tabular}{|l|l|l|l|l|l|}
\hline Study area & Strongly agree & Agree & Nutral & Disagree & Strongly disagree \\
\hline Adama & $6(2.4)$ & $31(12.4)$ & $9(3.6)$ & $96(38.4)$ & $108(43.2)$ \\
\hline Addis Ababa & $16(5.3)$ & $53(18.3)$ & $12(4.2)$ & $92(30.7)$ & $127(42.3)$ \\
\hline Total & $22(4.2)$ & $84(15.3)$ & $21(3.8)$ & $188(34.2)$ & $235(42.7)$ \\
\hline
\end{tabular}

Source: (Field Data, 2018)

Concerning the public participation phenomenon in the study areas, the insignificant number of respondents, that is, 106(19.3\%) of them in both cities were positively replied that the officials invited the public to get feedback or input on the services they delivered. However, the majority of respondents, that is, $108(43.2 \%)$ of them in Adama and 127 (42.3\%) of the respondents in Addis Ababa complied with strongly disagree which totally accounts to $423(76.9 \%)$ of the respondents. These should be given a due emphasis as participation will give citizens the opportunityof influencing decisions about public services, by providing objective evidence, which will determine service deliveries priorities. It can also help to facilitate a more participative and co-operative relationship between the providers and users of publicservices.

- Modes of participation practiced

Table 4.3. Modalities of public participation during service delivery

\begin{tabular}{|l|l|l|l|l|}
\hline olumn1 & Collaborate & Involve & Consult & Inform \\
\hline Adama & $5(0.135)$ & $7(0.1890$ & $9(0.243)$ & $16(0.432)$ \\
\hline Addis Ababa & $8(0.116)$ & $11(0.159)$ & $21(0.304)$ & $29(0.420)$ \\
\hline Total & $13(2.4)$ & $18(3.27)$ & $30(5.5)$ & $34(6.2)$ \\
\hline
\end{tabular}

(Field Data, 2018)

From the service users that are participated, as shown in the above table, majority of them , that is, 34(6.2\%) of the respondents are categorized under informed. However, informing the public is leveled as the passive participation as people participate only told what is going to happen or what has already happened. In this regard, the insignificant number, that is, $13(2.4 \%)$ of the respondents are categorized under desired type of participation, which is colabortation in both study cities. In collaboration, the public is provided with opportunity to partner or work jointly with decision-makers and the identification of the preferred solution. In these type of participation all the input received will be taken into account and the managers of the respective sectors will make the final decision.

- Service standards

Table 4.4: Setting Service standards

\begin{tabular}{|l|l|l|l|l|l|}
\hline Study area & Strongly agree & Agree & Nutral & Disagree & Strongly disagree \\
\hline Adama & $19(7.6)$ & $54(21.60)$ & $23(9.20)$ & $85(3.4)$ & $69(27.60)$ \\
\hline Addis Ababa & $32(10.60)$ & $69(0.228)$ & $34(11.2)$ & $89(29.4)$ & $79(26.1)$ \\
\hline Total & $51(9.3)$ & $123(22.36)$ & $57(10.4)$ & $174(31.6)$ & $148(26.9)$ \\
\hline
\end{tabular}

* The Number in the bracket indicates Percentages out of hundred

Source: (Field Data, 2018)

In relation to service standards, as shown in the above table, majority of the respondents, that is, $322(58.5 \%)$ of them added together in both cities have strongly disagree confirming that they have not been given any service standards by the officials in the study institution of the government. However, service standards must be set at a level which is demanding but realistic. In fact, it should reflect a level of service, which is higher than that currently offered but which can be achieved with dedicated effort and by adopting more efficient and customer-focused working practices. 
- $\quad$ Equal access to service.

Table 4.5:Equal access to different services

\begin{tabular}{|l|l|l|l|l|l|}
\hline Study area & Strongly agree & Agree & Nutral & Disagree & Strongly disagree \\
\hline Adama & $6(0.024)$ & $45(0.18)$ & $3(0.012)$ & $88(0.352)$ & $108(0.432)$ \\
\hline Addis Ababa & $8(0.027)$ & $103(0.34)$ & $18(0.06)$ & $67(0.22)$ & $104(0.35)$ \\
\hline Total & $14(2.55)$ & $148(26.9)$ & $21(3.81)$ & $155(28.1)$ & $212(38.6)$ \\
\hline
\end{tabular}

Source: (Field Data, 2018)

As to equal access to the service by the respondents, see table above, $43.20 \%$ in Adama and $34.67 \%$ of the them in Addis Ababa respectively have strongly disagreed confirming that citizens have no equal access to services rendered by government. In the same manner, $35.20 \%$ and $22.33 \%$ of respondents in Adama and Addis Ababa respectively have disagreed aboue equal service access to all residents in the cities. Such barriers to access public services need to be taken into account.

- Courtesy

Table 4.5:Treating customers with Courtesy

\begin{tabular}{|l|l|l|l|l|}
\hline Study Area & Strongly agree & Agree & Disagree & Strongly disagree \\
\hline Adama & $12(4)$ & $73(24)$ & $119(40)$ & $96(32)$ \\
\hline Addis Ababa & $34(11)$ & $79(26)$ & $105(35)$ & $82(27)$ \\
\hline Total & $46(15)$ & $152(50)$ & $224(75)$ & $178(59)$ \\
\hline
\end{tabular}

Source: (Own Data, 2018)

With regard to treating customers with courtesy, as depicted in above taable, 96(32\%)of the respondents in Adama and $82(27.33 \%)$ of them in Addis Ababa have strongly disagreed confirming that they were not treated as customers. Furthermore, 119(39.67\%) of the respondents in Adama and 105(35\%) of them in Addis Ababa disagreed the existence of curtesy in the delivery of public service. However, courtesy and regard for the public is one of the fundamental duties of public servants, by specifying that public servants treat members of the public as customers who are entitled to receive the highest standards of service. However, there are some,73(24.33\%) of the respondents in Adama and 79(26.33\%) of them in Addis Ababa, have confirmed that they are treated with respect and consideration when they interact with the officials.

- Access to Information

Table 4.6: Information about the services

\begin{tabular}{|l|l|l|l|l|}
\hline Study area & Strongly agree & Agree & Disagree & Strongly disagree \\
\hline Adama & $2(.008)$ & $21(0.084)$ & $112(0.448)$ & $115(0.46)$ \\
\hline Addis Ababa & $6(0.02)$ & $13(0.043)$ & $183(0.61)$ & $98(0.33)$ \\
\hline Total & 8 & 34 & 295 & 214 \\
\hline
\end{tabular}

Source: (Own Data, 2018)

With reference to access to information about the services, as shown in the above table, $115(46 \%)$ of the respondents in Adama and 98(32.67\%) of them in Addis Ababa were in the category of strongly disagree while $112(44.8 \%)$ of respondents in Adama and 183(43\%) of them in Addis Ababa were in the category of disagree. However, citizens should have been given information that is accurate about government services they are entitled to, as this will in turn enable them to make informed choices about services they require. This could be done in a number of ways-for example through newspapers, radio, posters and leaflets.

- $\quad$ Redressing mistakes swiftly

Table 4.7: Speedy remedy is offered for the failure of promised service

\begin{tabular}{|l|l|l|l|l|l|}
\hline Study area & Strongly agree & Agree & Nutral & Disagree & Strongly disagree \\
\hline Adama & $12(0.048)$ & $34(0.136)$ & $25(0.1)$ & $71(0.284)$ & $108(0.432)$ \\
\hline Addis Ababa & $32(0.107)$ & $65(0.23)$ & $34(0.11)$ & $71(0.24)$ & $98(0.33)$ \\
\hline Total & $44(8)$ & $99(18)$ & $59(10.7)$ & $142(25.8)$ & $206(37.46)$ \\
\hline
\end{tabular}

Source: (Own Data, 2018)

In relation to redressing mistakes swiftly and sympathetically, 108(43.2\%) of the respondents in Adama and 98(33\%) of them in Addis Ababa were categorized as strongly disagree while $71(28.4 \%)$ of the respondents in Adama and 71(24\%) of them in Addis Ababa were categorized in disagree to the existence and practice of redress for the failure of the service that were pledged to be given. However, 143(26\%) of the respondents positively replied that speed remedy is given by the institution under study. FGD and interview result also corroborate with the survey analysis as the discussants confirmed the absence of redress by arguing for the practice of an apology, full explanation and speedy remedy when the promised standards of service have not been delivered. 
- Value for many and the best use of resources

Table 4.8: The best use of resources avoiding wastage of money

\begin{tabular}{|l|l|l|l|}
\hline Study Area & Neutral & Disagree & Strongly disagree \\
\hline Adama & $43(14)$ & $135(45)$ & $122(41)$ \\
\hline Addis Ababa & $54(18)$ & $113(38)$ & $133(44)$ \\
\hline Total & $97(32)$ & $248(83)$ & $255(85)$ \\
\hline
\end{tabular}

Source: (Own Data, 2018)

Concerning value for many and the best use of resources, $122(41 \%)$ of the respondents in Adama and $133(44 \%)$ of them in Addis Ababa fall in the category of strongly disagree while $135(45 \%)$ and $113(38 \%)$ of them were in the category of disagree respectively. These have revealed that there are wastage of public services though the public servant should make the best use of available resources by avoiding wastage of time, money, and other resources. Only 43(14\%)of the respondents in Adama and 54(18\%)of them in Addis Ababa were in different regarding the existence of the best use of resources avoiding wastage of money in the study cities.

\section{- Openness and transparency}

Table 4.9: Openness and transparency about the money received and spent

\begin{tabular}{|l|l|l|l|l|lr|}
\hline Study area & Strongly agree & Agree & Nutral & \multicolumn{2}{|l|}{ Disagree } & \multicolumn{2}{|l|}{ Strongly disagree } \\
\hline Adama & $14(0.056)$ & $34(0.136)$ & $18(0.072)$ & $97(0.388)$ & $87(0.348)$ & \\
\hline Addis Ababa & $31(0.10)$ & $47(0.16)$ & $23(0.08)$ & $98(0.33)$ & $101(0.34)$ & \\
\hline Total & & 85 & 41 & 195 & \\
\hline
\end{tabular}

Source: (Own Data, 2018)

With reference to openness and transparency about the money received and how that money is spent, $142(56.80 \%)$ of respondents in Adama and 185(61.67\%) of them in Addis Ababa were in the category of strongly disagree while that of 98(39.20\%) respondents in Adama and 98(32.67\%) of them in Addis Ababa fell in disagree category. The major aspect of this is that the public should know more about the way national and provincial departments are run, how well they perform, the resources they consume, and who is in charge. Only 10(4\%) of the respondents in Adama and 17(5.67\%) of them in Addis Ababa were in different about the openness and transparencyabout the money received and how that money is spent by the officials entitled to deliver public service.

\section{Conclusion}

The study concluded that while ineffective service delivery are considerable challenges faced by public service, they are not insurmountable. Especially, the principles that can objectively guide the public service institutions, not only on service delivery standards, but also on public participation as well is not strictly followed by the institution under study. The stiudy acknowledged a significant progress made by creating governance structures at sub-national levels to provide and accelerate the delivery of essential services to citizens. However, more still need to be done to improve the socio-economic welfare of the people. The budgetary constraints and lack of capacity in the form of human resource raised by the majority of FGD participant in each sector need to be addresed.

Citizens are not just consumers of services rendered by government, but are also critical role players with a stake in the election of governments and how such governments should run the affairs of the country. Given this, it is important that government ensures meaningful mechanisms for effective service deliveries, especially in the implementation of government policies and programs. People, as both citizens and consumers of services, should be allowed and encouraged to express their views on governance and service deliveries matters.

\section{References}

Ackerman, J.M. (2004b): "Co-governance for Accountability: Beyond 'Exit' and 'Voice,' in World Development 447-463.

Baines, A. 1996.Designing Customer Service Programmes. Work Study. Vol. 45, No. 1, 1996.

Batley, Richard (2004) “The Politics of Service Delivery Reform", Development and Change, Vol. 35, Issue 1, (pp: 31-56). Available from: <www.blackwellsynergy.com> [Accessed 30 January 12008 ]

Biela, J. and Y.(2010) Papadopoulos. "Strategies for Assessing and Measuring Agency Accountability." Conference Paper presented at the 32 European Group for Public Administration (EGPA) Annual Conference.

Blair, H. (2000) "Participation and Accountability at the Periphery: Democratic Local Governance in Six Countries," in World Development

Claasen, M. and C. (2011).Alpín-Lardiés.SocialAccountability in Africa: Practitioners' Experiences and Lessons.Cape Cities, South Africa: IDASA.

Denhardt, J. V., Denhardt, R. B. (2003). The New Public Service: Serving, not steering.

developing countries, Delft, The Netherland

Ebdon, C. (2002). Beyond the public hearing: Citizen participation in the local government 
Economic Policy I, Duck worth, London

Glaser, M. A., Yeager, S. J., Parker, L. E. (2006). Involving citizens in the decisions of public affairs

Goetz, A.M. and J. Gaventa. (2001)"Bringing Citizen Voice and Client Focus into Service Deliveries." Institute of Development Studies (IDS) Working Paper 138. England

Kelly, J. M., Swindell, D. (2002). A multiple-indicator approach to municipal service

Lowndes, V., Pratchett, L., Stoker, G. (2001). Trends in public participation: part 1- local

Ngouo, L.B. 1997. Responsibility and Transparency in Governmental Organisations in Cameroon:No.721/2011 